\title{
Весёлкина М.В.
}

\section{Воздействие творческого процесса на образовательно- воспитательное развитие общественного сознания}

\author{
Vesyolkina M.V. \\ The impact of creative process on the educational \\ development of public consciousness
}

В статье рассматриваются основные элементы творческого процесса и его воздействие на образовательно-воспитательное развитие общественного сознания, с помощью постановки творческих задач и эстетической деятельности. Статья носит обзорный ознакомительный характер и оставляет место для дальнейшего глубокого изучения предмета

Ключевые слова: образовательно-творческий процесс, эстетическая деятельность

\section{Весёлкина Мария Вячеславовна}

Ассистент

Омский государственный институт сервиса г. Омск, ул. Певцова, 13
This article discusses the basic elements of the creative process and its impact on the educational development of public consciousness, with performances of creative tasks and aesthetic activity. The article is an overview of familiarization character and leaves room for further in-depth study of the subject

Key words: educational-creative process, social consciousness, aesthetic activities

\author{
Vesyolkina Mariya Vyacheslavovna \\ Assistant \\ Omsk state institute of service \\ Omsk, Pevtsova st., 13
}

Творчество и эстетическое наслаждение являются фундаментальными чертами человеческой жизни. Когда человек поглощен такого рода активностью, его мозг действует гораздо более интенсивно, чем во время обычной деятельности. Его мировосприятие меняется и наполняется большим количеством красок. Творческая деятельность направлена на создание качественно новых общественных ценностей. Стимулом к общественной деятельности служит проблемная ситуация, которую невозможно разрешить на основе имеющихся данных традиционными способами. Оригинальный продукт деятельности получается в результате нетрадиционной взаимосвязи элементов проблемной ситуации, привлечение неявно связанных элементов, установление между ними новых видов взаимозависимости. Предпосылками творческой деятельности являются гибкость мышления (способность варьировать способы решения), критичность (способность отказываться от непродуктивных стратегий), способность к сближению и сцеплению понятий, целостность восприятия и другое $[2$, с. 6]. 
В творческую деятельность, если она становится жизненным призванием, вовлечен весь человек, с присушим ему отношением к действительности, с его убеждениями и взглядами, с основным кругом его запросов и интересов, с миром его чувств и побудительных мотивов его поведения. В обыденной жизни человек часто даже просто не задумывается над качеством своих переживаний, но есть сферы творческого труда, где работают с эмоциями как материалом. Прежде всего это литература, сценическое искусство, композиция и музыкальное исполнительство. Здесь эмоциональные образы не спонтанно-наивно переживаются, а сознательно создаются, спонтанно-профессионально изображаются и передаются. Познание чувств требует их отделения и трансформацию в форму, пригодную для сознательного освоения, управления и использования в творческих целях. Эти возможности реализуются наиболее явно и полно в литературе и искусстве. Художественно - эстетическое воспитание - это одно из необходимых предпосылок повышения общей культуры человека, становления его как духовной сущности, понимающей себя и мир вокруг себя. Одна из важнейших задач воспитания - выявление склонностей и дарований, развитие в соответствии с индивидуальными особенностями человека, его способностями и возможностями [3, с. 9]. Нет истинного творчества без мастерства, без высокой требовательности, упорства и работоспособности, без таланта, который на девять десятых состоит из труда. Однако все эти качества ничего не стоят без художественной концепции мира, без мировоззрения, вне целостной системы эстетических принципов, претворяемых в образы. Мировоззрение художника зависит не только от количества изученных им философских истин. Оно рождается в самой жизни - из наблюдений над природой и обществом, из усвоения культуры человечества, из активного отношения к миру. Мировоззрение не только руководит талантом и мастерством, оно и само формируется под их воздействием в процессе творчества $[1$, с. 4]. Искусство доставляет одно из высших духовных переживаний - эстетическое наслаждение. Однако без эстетики нет художественной образованности, а без последней нет наслаждения искусством. Эстетическое воспитание гармонизирует и развивает все духовные способности человека, необходимые в различных областях творчества. Оно тесно связано с нравственным воспитанием, так как красота выступает своеобразным регулятором человеческих взаимоотношений. Благодаря красоте человек часто интуитивно тянется и к добру. По-видимому, в той мере, в какой красота совпадает с добром, можно говорить о морально-нравственной функции эстетического воспитания. Эстетика и есть воспитатель истинного восприятия искусства. Эстетическая деятельность - это деятельность человека в ее общечеловеческой значимости. Универсальной формой эстетической деятельности является творчество по законам красоты. Основу эстетической деятельности составляет искусство. Именно искусство - универсальный источник и средство развития творческих способностей человека, образного мышления, эмоциональной сферы, художественно-эстетического сознания, как сознания, остро видящего дисгармонию в происходящем и способное эти недостатки преодолеть и привести в согласие. 
Основой художественно - эстетического сознания личности является художественная и эстетическая потребность. Для развития творческого мышления необходимы не отдельные творческие эксперименты, а системы творческих задач, в процессе выполнения которых формируются и развиваются логические операции. Творческая задача - это задача, для выполнения которой требуется изменение изученных правил или самостоятельное составление новых правил и в результате решения которой создаются субъективно или объективно новые системы - информация, конструкции, вещества, явления, произведения искусства. Отличительными признаками тех предметов, процессов, решений задач, идей или произведений искусства, которые принято называть творческими, являются, как правило, новизна или уникальность, полезность у технических решений или эстетическая ценность у произведений искусства, изящество (т. е. внесение простоты туда, где раньше была сложность). Для творческих решений характерно также создание новых соотношений, так как прежде не связанные элементы при объединении часто дают новый единст-венный в своем роде эффект [2, с. 3]. По этим признакам к творческим относят огромное количество решений, которые тем не менее внутри этой группы существенно отличаются степенью новизны и оригинальности, общественной значимости и полезности. Познание -активный творческий процесс поиска нового, оригинального и даже уникального - того, чего раньше не было. В этом процессе "задействованы" все таланты и способности познающего - его органы чувств, память, мышление, воображение, фантазия, интуиция и др. - в их единстве и взаимодействии. Важная особенность творческого познания - умение создавать и успешно разрешать проблемные ситуации. Творческое познание невозможно без самостоятельности мышления, его критичности и самокритичности, гибкости мышления, умения делать выводы из допущенных ошибок, мыслить быстро (но не скоропалительно), отделять существенное от несущественного и самостоятельно приходить ко все новым и новым выводам и обобщениям.

Искусство - всестороннее развитие социально значимой и самоценной личности, формирование ее потребностей и ценностных ориентации. В результате чего искусство способно одухотворить науку и технику, осветить всё идеями гуманизма. Развитие человека, его непрерывное совершенствование идут через общество, во имя людей, а развитие общества - через человека, во имя личности. В этой диалектике человека и человечества - смысл и суть истории. Способствовать историческому прогрессу во имя счастья человека - высшее гуманное назначение искусства. Тем самым творчество - это деятельность, порождающая нечто качественно новое и отличающаяся неповторимостью, оригинальностью и общественно-исторической уникальностью. Оно очень важно для формирования активного общественного сознания, так как всегда предполагает творца - субъекта творческой деятельности - создающего новые по замыслу материальные, культурные, духовные ценности. Познание и творчество неразрывно связаны как между собой, так и с практикой (практической деятельностью) как с их основой. 


\section{Список используемых источников:}

1. Борев Ю.Б. Эстетика. М.: Политиздат, 1988. 386 с.

2. Иванов Г.И. Формулы творчества или как научиться изобретать. М.: Просвещение, 1994.

3. Альтшуллер Г.С. Найти идею. Новосибирск: Наука, 1986.

\section{(C) 2015, Весёлкина М.В.}

Воздействие творческого процесса на образовательно-воспитательное развитие общественного сознания
(C) 2015, Vesyolkina M.V.

The impact of creative process on the educational development of public consciousness 